\title{
Prevalence, antimicrobial resistance profile and comparison of selective plating media for the isolation of Salmonella in backyard chickens from Entre Rios, Argentina
}

\author{
F. I. Rodríguez ${ }^{1,2}$ | D. C. Pascal ${ }^{3}$ | D. Pulido ${ }^{4}$ | J.M. Osinalde ${ }^{5}$ M. M. Caffer ${ }^{6}$ | \\ D. J. Bueno 1,3
}

${ }^{1}$ Instituto Nacional de Tecnología Agropecuaria EEA Concepción del Uruguay, Concepción del Uruguay, Argentina

${ }^{2}$ Consejo Nacional de Investigaciones Científicas y Técnicas (CONICET), Laboratorio de Sanidad Aviar, Instituto Nacional de Tecnología Agropecuaria EEA Concepción del Uruguay, Concepción del Uruguay, Argentina

${ }^{3}$ Facultad de Ciencia y Tecnología, Sede Basavilbaso, Universidad Autónoma de Entre Ríos, Basavilbaso, Argentina

${ }^{4}$ Fundación ArgenINTA, Paraná, Argentina

${ }^{5}$ Dirección General de Recursos Naturales, Ministerio de Producción de Entre Ríos, Paraná, Argentina

${ }^{6}$ Servicio de Enterobacterias, Instituto Nacional de Enfermedades Infecciosas (INEI) ANLIS "Dr Carlos G. Malbrán", Ciudad de Buenos Aires, Argentina

\section{Correspondence}

Dante Javier Bueno, Instituto Nacional de Tecnología Agropecuaria EEA Concepción del Uruguay, Concepción del Uruguay, Argentina. Email: dantejb@yahoo.com.ar

Funding information

National Institute of Agricultural Technology (INTA, Specific Project 1115056), and Ministry of Science, Technology and Productive Innovation, Argentina (PFIP-ESPRO 2009)

\begin{abstract}
Summary
This study was conducted to estimate the apparent prevalence of Salmonella spp. in birds kept under backyard system in Entre Ríos, Argentina, and determine the performance of two selective plating media used for Salmonella isolation, and the antimicrobial resistance of the isolated. Also, the association of farms characteristics with Salmonella presence was evaluated. A total of 657 backyard chickens and 15 gooses were sampled one time by cloacal swab, belonging to 51 and one family farms, respectively, and four counties in Entre Rios state from April 2014 to May 2015. Only four samples from backyard chickens belonged to three family farms from Uruguay County were positive to Salmonella spp., so the apparent prevalence was $0.6 \%$ for this kind of chicken. Four serovars were isolated (Salmonella ser. Lille, S. ser. Newport, S. ser. Enteritidis and S. ser. Rissen), which were susceptible to all antibiotics tested with the exception of erythromycin. For Hektoen enteric agar and brilliant green agar, relative specificity and positive predictive value were 1 , and the relative sensitivity and negative predictive value did not show any difference between them. The agreement was very good between these two plating media. None of the variables studied could be selected to calculate the risk factors associated with Salmonella isolation because $p>$.15. Although the prevalence of Salmonella spp. is low in backyard birds in Entre Rios, the presence of $S$. ser. Enteritidis should not be discounted, because it is found in the county that concentrates a large population of intensive poultry production in the state.
\end{abstract}

KEYWORDS

Argentina, backyard chicken, plating media, Salmonella

\section{1 | INTRODUCTION}

In Argentina, as in other developing countries, there is a sizable backyard poultry industry that, together with large-scale commercial producers, supplies domestic markets. The governments have adopted a system to breed backyard chickens and give them to low-income people so that they can have high-quality protein in their diets (Bonino $\&$ Canet, 1999). Backyard or free range evokes a positive image of chickens living outdoors with plenty of fresh air, sunshine and open space to roam in, and they have contact with other animals (Freire, Melo, dos Santos Silva, \& da Silva, 2005; Kperegbeyi, Meye, \& Ogboi, 2009; SA PPLPP, 2009). Furthermore, small poultry keepers have limited contact with veterinarians and their biosecurity practices are poor compared with enterprises. Thus, backyard chickens become a possible reservoir for bacteria like Salmonella and sometimes could be 
involved in avian disease outbreaks with negative influence in commercial poultry production (Beam, Garber, Sakugawa, \& Kopral, 2013; Kelly et al., 1994; Manning, Gole, \& Chousalkar, 2015). Infected poultry flocks are also among the most frequently implicated reservoirs of salmonellae that can be transmitted through the food chain to humans. Poultry producers are faced with intensifying pressure from public health authorities, elected officials and consumers regarding food safety issues (Gast, 2003).

The genus Salmonella consist of only two species: Salmonella enterica and Salmonella bongori. Salmonella enterica is divided into six subspecies and more than 2,500 serovars; some of them can be important pathogens in humans and animals, with varying levels of host specificity (Issenhuth-Jeanjean et al., 2014; Singer, Mayer, Hanson, \& Isaacson, 2009). Fowls are the specific host of Salmonella enterica ser. Gallinarum biovar Pullorum and Gallinarum, which cause pullorum disease and fowl typhoid, respectively. Other serovars with no specific host, such as S. ser. Typhimurium and S. ser Enteritidis (SE), may infect humans, chickens and other animals (Guard-Petter, 2001).

Cloacal swabs or samples of voided faeces have been used to provide evidence of persistent intestinal colonization by salmonellae in individual birds (Gast, 2013). Culture methods are used in laboratory procedure recommended for the bacteriological examination of Salmonella in the Poultry Improvement Plan of different countries (Barroso, 2010, 2011, 2012; National Agrifood Health and Quality Service, 2003, 2016, United States Department of Agriculture, 2017). However, the process of isolating Salmonella is to some extend prone to failure. Depending on the type of competitive bacteria, detection of occasional colonies of Salmonella may be easier if the appropriate plating medium has been used. Unfortunately, the composition of the flora is never known in advance. Therefore, the appropriate plating medium may not be used for culture. Numerous agar media are available for the isolation of salmonellae (Busse, 1995; Gast, 2013; Soria \& Bueno, 2016). Furthermore, Antibiotics are used as veterinary medicine for treatment and prevention of diseases, as prophylactic agents in the water of healthy birds and also as growth promoters in low concentrations in food (Apata, 2009; Phillips et al., 2004). The efficacy and wisdom of medication with these drugs to prevent or treat Salmonella infections in poultry are topics of considerable debate because of the inconsistent history of these drugs in eliminating Salmonella colonization and because indiscriminate veterinary and agricultural uses may imperil their medical usefulness by promoting microbial resistance (Gast, 2013; Shivaprasad \& Barrow, 2008). The potential risk of genetic exchange that exists in the intestine is one of the reasons that explain a zoonotic risk of transfer of resistance (Errecalde, 2004).

There are few studies of Salmonella on backyard poultry in Argentina. Although some Salmonella serovars control plan is included in the National Poultry Health Plan in Argentina for breeders, broilers and hens (National Agrifood Health and Quality Service, 2003, 2016), backyard chickens play a significant socio-economic role in poor communities, and their flocks are not usually monitored for diseases or vaccinated. Xavier et al. (2011) found that the seropositive family farms were between 0\% and $66.7 \%$ for Salmonella in Entre Rios, Argentina, during the period 2003-2007. However, these authors did not try to

\section{Impacts}

- The prevalence of Salmonella spp. is low in backyard chickens in Entre Rios, Argentina.

- Salmonella strains isolated are resistant to erythromycin.

- Hektoen enteric agar is very similar to Brilliant green agar for Salmonella sp. isolation from cloacal swab samples in backyard chickens.

isolate this bacteria. It is well recognized that some animals or poultry with a positive serological response may no longer be infected with Salmonella organisms. Likewise, animals or poultry that are actively excreting salmonellae may be serologically negative (World Organization for Animal Health, 2008).

Entre Ríos is a state in Argentina where poultry production is so concentrated that, from an epidemiological point of view, it is similar to a very large multi-age farm. This state is divided into 17 counties (Uruguay County concentrated $31 \%$ of the poultry farm and hatcheries) and has almost 3,355 poultry houses, which correspond to $43 \%$ of the poultry houses from Argentina. It also accounts for almost $48.7 \%$ of the poultry production and $25.2 \%$ of the egg production in Argentina (Livestock, Pigs and Poultry Division, 2014, Ministry of Agrindustry, 2016). Therefore, the present study was conducted to (i) estimate the apparent prevalence of Salmonella in birds kept under backyard system in Entre Ríos, Argentina, (ii) determine the performance of two differential plating media used in a sample for Salmonella isolation, and the antibiotic resistance profile of the isolated and (iii) study the association of farm characteristics with Salmonella presence in these types of farms.

\section{2 | MATERIAL AND METHODS}

\section{1 | Study design}

A total of 657 backyard chickens were sampled one time by cloacal swab from April 2014 to May 2015. These animals belonged to 51 family farms and four counties in Entre Rios state (Table 1). The number of cloacal swabs from backyard chickens was based on the following equation (Mateu \& Casal, 2003), with an expected prevalence of $50 \%$ and a precision of $5 \%$ with $99 \%$ confidence limit:

$$
n=Z^{2} p q / B^{2}
$$

where: $n=$ sample size, $Z=2.56$ for $99 \%$ confidence limit, $p=$ disease expected frequency (0.5), $q=1-p, B=$ precision.

Five to 15 samples were taken from each backyard chicken farm. Furthermore, 15 gooses from another family farm were sampling by cloacal swab. A sterile cotton swab, pre-moistened with sterile $0.85 \% \mathrm{CINa}$ solution, was inserted into the cloaca of each bird and rotated gently against the lining of the cloaca to collect a sample. Swab from each bird was transferred to an independent sterile tube. 
TABLE 1 Number of family farms and cloacal swab tested in the different counties from Entre Ríos, Argentina, from April 2014 to May 2015

\begin{tabular}{|c|c|c|}
\hline County of Entre Ríos & No. of farms & $\begin{array}{l}\text { No. of } \\
\text { cloacal } \\
\text { swab } \\
\text { tested }\end{array}$ \\
\hline Colon & 1 & 15 \\
\hline Gualeguaychu & 1 & 5 \\
\hline Tala & 3 & 45 \\
\hline Uruguay & 46 & 592 \\
\hline Total & 51 & 657 \\
\hline
\end{tabular}

Samples were labelled and transferred to the INTA Laboratory of Poultry Health (Concepción del Uruguay, Entre Ríos) in ice chests for Salmonella isolation.

\subsection{Salmonella spp. isolation and identification}

At the laboratory, $5 \mathrm{ml}$ of tetrathionate broth (Acumedia, Michigan, USA) plus supplements ( $20 \mathrm{ml} / \mathrm{L}$ of iodine-potassium iodide solution $-6 \mathrm{~g}$ of iodine and $5 \mathrm{~g}$ of potassium iodide; $20 \mathrm{ml}$ of demineralized water-brilliant green $0.1 \%$, Sigma, Steinheim, Germany; and $40 \mathrm{mg} / \mathrm{ml}$ of novobiocin, Sigma) was added to each tube with cloacal swab. After incubation during $18-24 \mathrm{hr}$ at $35 \pm 2{ }^{\circ} \mathrm{C}$, a loopful of broth was streaked on Hektoen enteric (HE) agar (Acumedia, HEA) and brilliant green (BG) agar (Oxoid, Basingstoke, UK) for chicken samples, and HE agar (Britania, Buenos Aires, Argentina) and Salmonella Shigella agar (Merck, Darmstadt, Germany) for goose samples, and incubated at $35 \pm 2^{\circ} \mathrm{C}$ for $18-24 \mathrm{hr}$. Two presumed Salmonella colonies on each selective-differential agar plate were biochemically confirmed using triple-sugar iron agar (Acumedia), lysine iron agar (Merck), Simmons citrate (Merck), sulphide indole motility medium (Merck), Jordan's tartrate agar, phenylalanine agar (Hi-Media, Mumbai, India) and urea agar (Britania). If there were no bacterial colonies compatible with Salmonella spp. in a selective-differential agar plate, two atypical Salmonella spp. colonies were also taken and the same biochemical tests, as mentioned before, were carried out. All Salmonella isolations were preserved on nutritive (Merck) slants agar until serotyping, which was carried out according to the White-Kauffmann-Le Minor scheme, with somatic $(\mathrm{AgO})$ and flagellar $(\mathrm{AgH})$ antigens (Grimont \& Weill, 2007).

\subsection{Antibiotic susceptibility test}

The antibiotic susceptibility test was performed by the standard disc diffusion method in Mueller-Hinton agar (Difco ${ }^{\mathrm{TM}}$, Sparks, USA) and the results were interpreted in accordance with the criteria of the National Committee for Clinical Laboratory Standards (2013, 2015). The isolates were screened for resistance to the following antibiotics: fosfomycin $(50 \mu \mathrm{g})$; colistin $(10 \mu \mathrm{g})$; tetracycline $(30 \mu \mathrm{g})$; florfenicol
(30 $\mu \mathrm{g})$; enrofloxacin $(10 \mu \mathrm{g})$; gentamicin $(10 \mu \mathrm{g})$; erythromycin $(15 \mu \mathrm{g})$; sulphamethoxazole/trimethoprim (25 $\mu \mathrm{g})$; doxycycline $(30 \mu \mathrm{g})$; neomycin $(30 \mu \mathrm{g})$; cephalothin $(30 \mu \mathrm{g})$; norfloxacin $(10 \mu \mathrm{g})$; amoxicillin $(10 \mu \mathrm{g})$; kanamycin $(30 \mu \mathrm{g})$; ciprofloxacin $(5 \mu \mathrm{g})$; chloramphenicol $(30 \mu \mathrm{g})$; cefotaxime $(30 \mu \mathrm{g})$; streptomycin $(10 \mu \mathrm{g})$; and fosfomycin/ tylosin $(160 \mu \mathrm{g} / 40 \mu \mathrm{g})$. All the antibiotic discs, except fosfomycin/ tylosin (FOSBAC PLUS T-BEDSON ${ }^{\mathrm{TM}}$, Britania), were purchased from Oxoid. The zone diameter breakpoint used for fosfomycin/tylosin was the same as fosfomycin.

\subsection{Analysis of the performance criteria for selective-differential culture media and statistical analysis}

Relative accuracy (RAc), sensitivity (RSe), specificity (RSp), positive predictive value (RPPV) and negative predictive value (RNPV) and agreement (kappa coefficient and McNemar's test) of HEA and BG agar, used for Salmonella spp. isolation from chicken cloacal swab samples, were analysed according to Soria, Soria, Bueno, and Colazo (2011). For isolation methodology, relative true positive was defined when a sample was positive to Salmonella spp. in at least one differential-selective agar. Relative true negative was defined as samples where Salmonella spp. was not detected in any differential-selective agar. Kappa coefficients were summarized, according to Dawson and Trapp (2004), as an excellent agreement (.93-1.00), a very good agreement (.81-.92), a good agreement (.61-.80), a fair agreement (.41-.60), a slight agreement (.21-.40), a poor agreement (.01-.20) and no agreement $(<.01) . Z$ test was used in order to test the statistical significance of kappa coefficients. On the other hand, McNemar's test was calculated using a chi-square approximation at $p \leq .05$ (GraphPad Software, 2017).

\section{5 | Relationships between different variables in a family farm and Salmonella presence}

Data concerning the general characteristics of the family farm, the feeding, watering and sanitary practices and the measures taken for Salmonella control were also collected. The questionnaire (related to 10 topics), consisting of questions of which most of them were close-ended (dichotomous or multiple choice), was filled out by the investigator during an interview with the farmer. Closed-ended questions were designed based on biosecurity measures for poultry farms, according to the Argentinean National Agrifood Health and Quality Service regulation 542/2010 (2010) and the resolution No. 52/2005 from Entre Ríos General Directorate of Animal Production (2005). Information from the questionnaires was coded and put in a database (Excel, Microsoft Cooperation). Data were analysed using INFOSTAT Software (Di Rienzo et al., 2014).

Each farm was considered a unit. A two-step statistical procedure was used to assess the relationship between the different variables (taken from the survey) and the Salmonella status in the farm sampled. All potential risk factors were tested by univariate analysis and only variables with a $p<.15$ were selected (Fisher or chi-square test). 


\section{3 | RESULTS}

\section{1 | Apparent prevalence of Salmonella in backyard poultry in Entre Ríos, Argentina, and antibiotic resistance profile of the isolated}

Of 657 samples of backyard chickens, only four samples, belonged to three family farms from Uruguay County, were positive to Salmonella spp. So the apparent prevalence was $0.6 \%$. Twelve Salmonella strains were isolated from those positive samples and were typified into four serovars (Table 2): Salmonella ser. Lille (4), S. ser. Newport (4), SE (3) and S. ser. Rissen (1). S. ser. Lille was isolated from two backyard chickens from the same family farm, while $S$. ser. Newport was isolated from two birds from different family farm. Furthermore, two different serotypes were isolated from one chicken in two cases (S. Lille-S. Rissen and S. Newport-SE). In reference to geese samples, Salmonella spp. was not isolated from them. On the other hand, Salmonella isolated strains revealed the same resistance pattern. All strains were susceptible to all antibiotics tested with the exception of erythromycin.

\section{2 | Performance of two selective-differential plating media used in a sample for Salmonella isolation}

Overall, four and three samples yield Salmonella spp. on HEA and BG agar, respectively. Because of the absence of false-positive samples, the RSp and RPPV were 1 for HEA and BG agar. There were not any statistical difference between HEA and BG agar in the RSe and the RNPV. The RAc was 1 for both selective agar plating. The RSe and RNPV was 1 (.52-1.00) for HEA. On the other hand, the RSe and RNPV were .71 (.26-.95) and 1.00 (.98-1.00) for BG agar, respectively. The agreement (kappa coefficient) was very good (.83) between HEA and BG agar, and McNemar's test showed that the difference between the two plating media was not statistically significant, with the two-tailed $p$-value of .4795 .

\section{3 | Association of farm characteristics with Salmonella spp. in backyard chicken in Entre Ríos, Argentina}

In relation to 51 family farms studied, $23.5 \%(12 / 51)$ of them use mains water. The remaining $76.5 \%$ (39/51) uses ground water and from this per cent, 15\% (6/39) usually disinfects it and makes microbiological analysis, 8\% (3/39) does not disinfect it, but makes analysis and 77\% (30/39) neither disinfects or makes analysis. Backyard chicken feeding includes feeds (44/51), kitchen waste (4/51) and homemade feeds (3/51). The disposal of mortalities makes by incineration (28/51), using as food for animals (3/51), laying far from the farm (6/51), using in a compost system $(9 / 51)$ and buried (5/51). In regard to the proximity of a commercial poultry enterprise, $52.9 \%$ (27/51) of backyard farms complies the national minimum required distance $(1,000 \mathrm{~m})$, while $47.1 \%$ (24/51) does not, and within this per cent, $33.3 \%(8 / 24)$ has both production systems in the same place. In respect of the proximity of a pig farm, $68.6 \%(35 / 51)$ of the farms complies the minimum state required distance $(1,000 \mathrm{~m})$, while the remaining $31.4 \%(16 / 51)$ does not, and within this per cent, $60 \%$
TABLE 2 Distribution of serovars of Salmonella isolated in Salmonella-positive backyard chicken farms in Entre Rios, Argentina

\begin{tabular}{lll|} 
Salmonella serovars & $\begin{array}{l}\text { No. of Salmonella- } \\
\text { positive cloacal swab }_{\text {samples }^{\text {a }}}\end{array}$ & $\begin{array}{l}\text { No. of } \\
\text { Salmonella- } \\
\text { positive family } \\
\text { farms }\end{array}$ \\
\hline Lille & 2 & 1 \\
\hline Newport & 2 & 2 \\
\hline Rissen & 1 & 1 \\
\hline Enteritidis & 1 & 1 \\
\hline
\end{tabular}

${ }^{a}$ Two different serotypes were isolated from the same bird in two backyard chickens.

$(9 / 15)$ has backyard poultry and pigs in the same area. None of the farmers has a written biosecurity plan, and only 9.8\% (5/51) has veterinary assistance. The $74.5 \%$ (38/51) of farmers makes rodent control, whereas none of them makes fly control. Finally, none of the farmers had reported Salmonella outbreaks. The results of the univariate analysis revealed that none of the variables studied could be selected to calculate the risk factors associated with Salmonella isolation because $p>.15$ (Table 3).

\section{DISCUSSION}

In the present study, the apparent prevalence of Salmonella in backyard chickens was $0.6 \%$. The application of rodent control, the use of industrial food (with some microbiological control) and the distance (more than $1,000 \mathrm{~m}$ ) from a pig and intensive poultry farms in most of backyard chicken farms sampled could help to decrease Salmonella sp. contamination in these animals. Although it was observed that the care and health of the birds was limited, coinciding with extensive breeding systems in Vietnam (Burgos, Hong Hanh, Roland-Holst, \& Burgos, 2007), the low prevalence of our study made it difficult to find Salmonella spp. risk factors. Isolation rates for Salmonella sp., using the same sample, were 5.8\% in Iran (Jafari, Ghorbanpour, \& Jaideri, 2007), 3.5\% in Paraguay (Leotta et al., 2010), 4\% in Morocco (Bouzoubaa, Lemainguer, \& Bell, 1992), 0.02\% in Australia (Manning et al., 2015) and $15 \%$ in West Bengal, India (Samanta et al., 2014). The difference between data could be attributed to the presence of different dominant serovars of Salmonella in each of the countries, and hence different rates of infection and shedding, differences in the general standard of health of the chickens in each country and biosecurity practices (Manning et al., 2015). It is known that cloacal swabs can provide sensitive indicators of persistent intestinal colonization in individual bird, but their diagnostic reliability is diminished by the intermittent shedding of salmonellae in the faeces of infected birds (Gast, 2013).

Reports of the frequency of isolation of Salmonella serovars from poultry sources around the world have yielded a wide range of results, although several serovars appear to be of continuing international significance. The unique epidemiologic association of $S$. ser Enteritidis with disease transmission via contaminated eggs has made the prevalence of this serovar a topic of particular interest (Gast, Guraya, \& 
TABLE 3 Results from univariate analysis for risk factors identification of Salmonella sp. The analysis describes the data from the 51 family farms of backyard chickens in Entre Rios, Argentina

\begin{tabular}{|c|c|c|c|}
\hline Variable & $\mathrm{n}$ & $\begin{array}{l}\% \text { of positive } \\
\text { family farm for } \\
\text { Salmonella sp. }\end{array}$ & $p$-Value \\
\hline \multicolumn{4}{|l|}{ Source of water } \\
\hline Well & 39 & 66.7 & \multirow[t]{2}{*}{.68} \\
\hline Mains & 12 & 33.3 & \\
\hline \multicolumn{4}{|l|}{ Feeding } \\
\hline $\begin{array}{l}\text { Commercial balanced } \\
\text { feed }\end{array}$ & 44 & 66.7 & \multirow[t]{3}{*}{.31} \\
\hline $\begin{array}{l}\text { Leftovers from human } \\
\text { consumption }\end{array}$ & 4 & 0 & \\
\hline Homemade feed & 3 & 33.3 & \\
\hline \multicolumn{4}{|l|}{ Carcass disposal } \\
\hline Incinerates dead birds & 28 & 66.7 & \multirow[t]{5}{*}{.67} \\
\hline $\begin{array}{l}\text { Uses as food for other } \\
\text { animals }\end{array}$ & 3 & 0 & \\
\hline $\begin{array}{l}\text { Throws it away from } \\
\text { the farm area }\end{array}$ & 6 & 0 & \\
\hline Compost system & 9 & 33.3 & \\
\hline Buries & 5 & 0 & \\
\hline
\end{tabular}

Distance to poultry house (enterprise)

$\begin{array}{llll}>1,000 \mathrm{~m} & 27 & 66.7 & .57 \\ \leq 1,000 \mathrm{~m} & 24 & 33.3 & \end{array}$

Distance to pig farm

$\begin{array}{llll}>1,000 \mathrm{~m} & 35 & 66.7 & .94 \\ \leq 1,000 \mathrm{~m} & 16 & 33.3 & \end{array}$

Veterinary assistance

$\begin{array}{lrrr}\text { Yes } & 5 & 0 & .56 \\ \text { No } & 46 & 100 & \end{array}$

Other animal species (not poultry)

$\begin{array}{lrrr}\text { Yes } & 51 & 100 & 1.00 \\ \text { No } & 0 & 0 & \end{array}$

Rodent control

$\begin{array}{llll}\text { Yes } & 38 & 66.7 & .81 \\ \text { No } & 13 & 33.3 & \end{array}$

Fly control

\begin{tabular}{lrrr} 
Yes & 0 & 0 & 1.00 \\
No & 51 & 100 & \\
Salmonella background & & & \\
Yes & 0 & 0 & 1.00 \\
No & 51 & 100 & \\
\hline
\end{tabular}

Guard, 2013). Different authors reported that cloacal swabs were not the best sample for detection of $S$. ser Enteritidis carriers in commercial layer farms (García, Soriano, Benítez, \& Catalá-Gregori, 2011; Mutalib, McDonough, Shin, Patten, \& Lein, 1992). In our study, this serovar was only isolated from one sample, indicating that this serovar is present, but with low incidence.
In our study, Salmonella strains were sensitive to 18 antibiotics tested, and only resistant to erythromycin, a macrolide antibiotic. Other authors reported a high resistant of Salmonella strains, isolated from poultry farms or clinical and environmental samples, to this antibiotic (El-Tayeb, Ibrahim, Al-Salamah, Almaary, \& Elbadawi, 2017; Phagoo \& Neetoo, 2015; Thung et al., 2016). Although the number of Salmonella strains isolated was low in our study and the resistant to this antibiotic could be due to improper usage or overuse, it is known that Gram-negative bacilli, as Salmonella sp., are usually intrinsically resistant to macrolide antibiotics (Chambers, 2006; Nakajima, 1999).

The objective of Salmonella spp. isolation in selective and differential plating media is to differentiate and separate the selected or target microorganism from the competitive microflora. It is recommended that samples should always be streaked onto two different media, preferably with dissimilar indicator systems for differentiating salmonellae from other organisms. This strategy decreases the number of the false-negative results, although with a little extra cost (Gast, 2013; Petersen, 1997). In our study, we used two selective and differential plating media: BG agar and HEA. Velma, Goo, Ching, and Gooch (1973) indicated that BG agar is more effective than $\mathrm{HE}$ agar in isolating salmonellae from food products. The selectivity of the first medium derives from the presence of brilliant green dye, lactose and sucrose, which are the basis for the differential capabilities of the media. Almost all Salmonella fail to ferment either lactose or sucrose and their colonies appear either pink to red, with reddening of the media (Waltman, 2000). On the other hand, the HE agar uses bile salts for selective inhibition and two indicator systems: (i) bromothymol blue and acid fuchsine as indicators of carbohydrate dissimilation (involve the sugars lactose, sucrose and salicin), and (ii) ferric iron as an indicator of the formation of hydrogen sulphide from thiosulphate. Most Salmonella do not ferment the three sugars, but produce $\mathrm{H}_{2} \mathrm{~S}$, which results in bluishgreen colonies with black centre (Van der Zee, 2003; Waltman, 2000). Although BG agar and HE agar use dissimilar indicator systems for differentiating salmonellae from other organisms, we did not find any difference in Salmonella isolation in both media and the agreement was very good between them without any statistical difference.

Temelli, Eyigor, and Carli (2010) evaluated the Salmonella serogroup detection in poultry meat samples by examining multiple colonies from selective plates following the FDA/BAM and ISO 6579 methods. They founded multiple serogroups ( $D$ and $E 4 ; B$ and $C 2 ; C 1$; G; and E1 and F) and concluded that a selective plate for Salmonella culture method can harbour more than one serogroup. In our study, two different serovars were isolated from one chicken in two cases (S. ser. Lille-S. ser. Rissen and S. ser. Newport-SE).

Although the prevalence of Salmonella spp. is low in backyard birds in Entre Rios with the isolation technique used, it should not be discounted, as S. ser. Enteritidis isolates were found only in the Uruguay County, which concentrates a large population of intensive poultry production in the state. On the other hand, because all Salmonella strains were only resistant to erythromycin, it is inadvisable to use this antibiotic to treat salmonellosis. Finally, the performance of HEA and BG agar is very similar for cloacal swab samples, so the combination of these two media for this kind of sample does not decrease the number of the false-negative results. 


\section{CONFLICTS OF INTEREST}

None of the authors have conflict of interests to declare.

\section{ACKNOWLEDGEMENTS}

This work was supported by grants from National Institute of Agricultural Technology (INTA, Specific Project 1115056), and Ministry of Science, Technology and Productive Innovation, Argentina (PFIP-ESPRO 2009). Francisco I. Rodriguez was supported by a fellowship from CONICET. We thank Mario A. Soria (EEA INTA Concepcion del Uruguay, Argentina), and Francisco Procura (CONICET- EEA INTA Concepcion del Uruguay, Argentina) for technical assistance. Preliminary results were presented as an Abstract at the XXIII Latin American Congress of Microbiology, Buenos Aires, Argentina, 26-30 September 2016.

\section{ORCID}

D. J. Bueno iD http://orcid.org/0000-0003-4334-6960

\section{REFERENCES}

Apata, D. F. (2009). Antibiotic resistance in poultry. International Journal of Poultry Science, 8, 404-408. https://doi.org/10.3923/ ijps.2009.404.408

Barroso, J. M. (2010). Commission Regulation (EU) No 200/2010 of 10 March 2010 implementing Regulation (EC) No 2160/2003 of the European Parliament and of the Council as regards a Union target for the reduction of the prevalence of Salmonella serotypes in adult breeding flocks of Gallus gallus. Official Journal of the European Union L61, 1-9.

Barroso, J. M. (2011). Commission Regulation (EU) No 517/2011 of 25 May 2011 implementing Regulation (EC) No 2160/2003 of the European Parliament and of the Council as regards a Union target for the reduction of the prevalence of certain Salmonella serotypes in laying hens of Gallus gallus and amending Regulation (EC) No 2160/2003 and Commission Regulation (EU) No 200/2010. Official Journal of the European Union L138, 45-51.

Barroso, J. M. (2012). Commission Regulation (EU) No 200/2012 of 8 March 2012 concerning a Union target for the reduction of Salmonella enteritidis and Salmonella typhimurium in flocks of broilers, as provided for in Regulation (EC) No 2160/2003 of the European Parliament and of the Council. Official Journal of the European Union L71, 31-36.

Beam, A., Garber, L., Sakugawa, J., \& Kopral, C. (2013). Salmonella awareness and related management practices in U.S. urban backyard chicken flocks. Preventive Veterinary Medicine, 110, 481-488. https://doi. org/10.1016/j.prevetmed.2012.12.004

Bonino, M. F., \& Canet, Z. E. (1999). Producción de pollos y huevos camperos. Boletín Técnico Dirección de Comunicaciones INTA. 39 pp.

Bouzoubaa, K., Lemainguer, K., \& Bell, G. J. (1992). Village chickens as a reservoir of Salmonella pullorum and $S$. gallinarium in Morrocco. Preventive Veterinary Medicine, 12, 95-100. https://doi. org/10.1016/0167-5877(92)90072-N

Burgos, S., Hong Hanh, P. T., Roland-Holst, D., \& Burgos, S. A. (2007). Characterization of poultry production systems in Vietnam. International Journal of Poultry Science, 6, 709-712. https://doi.org/10.3923/ ijps.2007.709.712

Busse, M. (1995). Media for Salmonella. International Journal of food Microbiology, 26, 117-131. https://doi.org/10.1016/0168-1605(93) E0030-U
Chambers, H. F. (2006). Protein synthesis inhibitors and miscellaneous antibacterial agents. In L. L. Brunton, J. S. Lazo, \& K. L. Parker (Eds.), The pharmacological basis of therapeutics (pp. 1173-1202). New York: The McGraw-Hill Companies Inc.

Dawson, B., \& Trapp, R. G. (2004). Basic and clinical biostatistics. New York, NY: McGraw-Hill Companies Inc.

Di Rienzo, J. A., Casanoves, F., Balzarini, M. G., Gonzalez, L., Tablada, M., \& Robledo, C. W. (2014). InfoStatversión Grupo InfoStat, FCA, Universidad Nacional de Córdoba, Argentina. Retrieved from http:// www.infostat.com.ar

El-Tayeb, M. A., Ibrahim, A. S. S., Al-Salamah, A. A., Almaary, K. S., \& Elbadawi, Y. B. (2017). Prevalence, serotyping and antimicrobials resistance mechanism of Salmonella enterica isolated from clinical and environmental samples in Saudi Arabia. Brazilian Journal of Microbiology, 48, 499-508. https://doi.org/10.1016/j.bjm.2016.09

Entre Ríos General Directorate of Animal Production (2005). Resolución No 5485/2005 S.P.G. Distancias mínimas entre granjas avícolas y porcinas. Retrieved from http://www.minagri.gob.ar/sitio/areas/d_gestion_ambiental/legislacion/provincial/_archivos/000002-Aves\%20 y\%20Porcinos/000008-Entre\%20R\%C3\%ADos/005485-resolucion_ n5485-2005_SPG\%20distancia\%20entre\%20establecimientos\%20 aviar\%20y\%20porcino.pdf

Errecalde, J. O. (2004). Uso de antimicrobianos en animales de consumo. Rome: Organización de las Naciones Unidas para la Agricultura y la Alimentación.

Freire, A. G., Melo, M. N., dos Santos Silva, F., \& da Silva, E. (2005). En el "alrededor de casa" los animales del traspatio. LEISA, 21, 8-10.

García, C., Soriano, J. M., Benítez, V., \& Catalá-Gregori, P. (2011). Assessment of Salmonella spp. in feces, cloacal swabs, and eggs (eggshell and content separately) from a laying hen farm. Poultry Science, 90, 1581-1585. https://doi.org/10.3382/ps.2010-01104

Gast, R. K. (2003). Paratyphoid infections. In Y. M. Saif, H. J. Barnes, A. M. Fadly, J. R. Glisson, L. R. Mcdougald \& D. E. Swayne (Eds.), Diseases of poultry (pp. 583-599). Ames, IA: lowa State Press.

Gast, R. K. (2013). Paratyphoid infections. In D. E. Swayne (Ed.), Diseases of Poultry (pp. 693-713, 718-733). Ames, IA: Wiley-Blackwell Publishing.

Gast, R. K., Guraya, R., \& Guard, J. (2013). Salmonella enteritidis deposition in eggs after experimental infection of laying hens with different oral doses. Journal of Food Protection, 76, 108-113. https://doi. org/10.4315/0362-028X.JFP-12-268

GraphPad Software (2017). McNemar's test to analyze a matched case-control study. Retrieved from https://graphpad.com/quickcalcs/ McNemar1.cfm

Grimont, P. A. D., \& Weill, F. X. (2007). Antigenic formulae of the Salmonella serovars. WHO Collaborating Centre for Reference and Research on Salmonella. Retrieved from https:/www.pasteur.fr/ip/portal/action/ WebdriveActionEvent/oid/01s-000036-089

Guard-Petter, J. (2001). The chicken, the egg and Salmonella enteritidis. Environmental Microbiology, 3, 421-430. https://doi. org/10.1046/j.1462-2920.2001.00213.x

Issenhuth-Jeanjean, S., Roggentin, P., Mikoleit, M., Guibourdenche, M., De Pinna, E., Nair, S., ... Weill, F. X. (2014). Supplement 2008-2010 (no. 48) to the White-Kauffmann-Le Minor scheme. Research in Microbiology, 165, 526-530. https://doi.org/10.1016/j.resmic.2014.07.004

Jafari, R. A., Ghorbanpour, M., \& Jaideri, A. (2007). An investigation in to Salmonella infection status in backyard chickens in Iran. International Journal of Poultry Science, 6, 227-229. https://doi.org/10.3923/ ijps.2007.227.229

Kelly, P. J., Chitauro, D., Rohde, C., Rukwava, J., Majok, A., Davelaar, F., \& Mason, P. R. (1994). Diseases and management of backyard chicken flocks in Chitungwiza, Zimbabwe. Avian Diseases, 38, 626-629. https:// doi.org/10.2307/1592089

Kperegbeyi, J. I., Meye, J. A., \& Ogboi, E. (2009). Local chicken production: Strategy of household poultry development in coastal regions of Niger Delta, Nigeria. African Journal of General Agriculture, 5, 17-20. 
Leotta, G., Suzuki, K., Alvarez, F. L., Nunez, L., Silva, M. G., Castro, L., ... Copes, J. (2010). Prevalence of Salmonella spp. in backyard chickens in Paraguay. International Journal of Poultry Science, 9, 533-536. https:// doi.org/10.3923/ijps.2010.533.536

Livestock, Pigs and Poultry Division (2014). Información de la Actividad Avícola en Entre Ríos. Dirección General de Ganadería, Ministerio de Producción. Retrieved from https://www.entrerios.gov.ar/minpro/ userfiles/files/Avicultura\%20para\%20la\%20web\%20datos\%202014_ Lucho_(1).pdf

Manning, J., Gole, V., \& Chousalkar, K. (2015). Screening for Salmonella in backyard chickens. Preventive Veterinary Medicine, 120, 241-245. https://doi.org/10.1016/j.prevetmed.2015.03.019

Mateu, E., \& Casal, J. (2003). Tamaño de la muestra. Revista Epidemiología Medicina Preventiva, 1, 8-14.

Ministry of Agrindustry (2016). Subsecretaria de ganadería. Segunda reunión de la comisión de ganadería y sanidad. Indicadores pecuarios. Retrieved from http://www.agroindustria.gob.ar/sitio/areas/cfa/ comisiones/actividad/_reunion_2/_material/ganaderia//000000_ Indicadores\%20Pecuarios.pdf

Mutalib, A., McDonough, P., Shin, S., Patten, V., \& Lein, D. (1992). Salmonella enteritidis in commercial layer farms in New York state; environmental survey results and significance of available monitoring tests. Journal of Veterinary Diagnostic Investigation, 4, 416-418. https://doi. org/10.1177/104063879200400408

Nakajima, Y. (1999). Mechanisms of bacterial resistance to macrolide antibiotics. Journal of Infectious and Chemotherapy, 5, 61-74. https://doi.org/10.1007/s101569900000 https://doi.org/10.1007/ s101560050011

National Agrifood Health and Quality Service (2003). Plan Nacional de Sanidad Avícola. Retrieved from http://www.aviculturaargentina.com. ar/sanidad/Micop_Salm.pdf

National Agrifood Health and Quality Service (2010). Resolución 542/2010. Retrieved from http://www.entrerios.gov.ar/minpro/userfiles/files/ PRODUCCION\%2OANIMAL/AVICULTURA/LEGISLACION/Res_senasa_542_10_1.pdf

National Agrifood Health and Quality Service (2016). Manual de procedimientos operativos programa de vigilancia y control de la contaminación por Salmonellas spp. en granjas avícolas. Retrieved from http:// www.senasa.gov.ar/sites/default/files/ARBOL_SENASA/ANIMAL/ AVES/PROD_PRIMARIA/SANIDAD_ANIMAL/MANUALES/resol. senasa_86_2016-manual_de_procedimientos_vigilancia_Y_control_ de_salmonella_spp._en_granjas_avicolas_comerciales_.pdf

National Committee for Clinical Laboratory Standards. (2013). Performance standards for antimicrobial disk and dilution susceptibility test for bacteria isolated from animals; approved standard, Third edition. CLSI document M31-A3. Wayne, PA: Clinical and Laboratory Standards Institute.

National Committee for Clinical Laboratory Standards. (2015). Performance standards for antimicrobial susceptibility testing; Twentieth Informational Supplement. M100-S20, 30, 1-153. Wayne, PA: Clinical and Laboratory Standards Institute.

Petersen, L. A. (1997). Comparison of EF-18 agar and modified brilliant green agar with Lutensit for isolation of Salmonella from poultry samples. Acta Veteterinaria Scandinavica, 38, 79-85.

Phagoo, L., \& Neetoo, H. (2015). Antibiotic resistance of Salmonella in poultry farms of Mauritius. Journal of World's Poultry Research, 5, 42-47.

Phillips, I., Casewell, M., Cox, T., De Groot, B., Friis, C. H., Jones, R., ... Waddell, J. (2004). Does the use of antibiotics in food animals pose a risk to human health? A critical review of published data. Journal of Antimicrobial Chemotherapy, 53, 28-52. https://doi.org/10.1093/jac/ dkg483

SA PPLPP (2009). Code: SAGP11, "Towards good livestock policies: Backyard poultry farming through self-help groups in West Bengal". Delhi: Good Practice Note.
Samanta, I., Joardar, S. N., Das, P. K., Sar, T. K., Bandyopadhyay, S., Dutta, T. K., \& Sarkar, U. (2014). Prevalence and antibiotic resistance profiles of Salmonella serotypes isolated from backyard poultry flocks in West Bengal, India. The Journal of Applied Poultry Research, 23, 536-545. https://doi.org/10.3382/japr.2013-00929

Shivaprasad, H. L., \& Barrow, P. A. (2008). Pullorum disease and fowl tuphoid. In Y. M. Saif, A. M. Fadly, J. R. Glisson, L. R. McDougald, L. K. Nolan \& D. E. Swayne (Eds.), Disease of poultry (pp. 620-636). Ames, IA: Blackwell Publishing. https://doi.org/10.1080/03079457.2010.542575

Singer, R., Mayer, A. E., Hanson, T. E., \& Isaacson, R. E. (2009). Do microbial interactions and cultivation media decrease the accuracy of Salmonella surveillance systems and outbreak investigations? Journal of Food Protection, 72,707-713.https://doi.org/10.4315/0362-028X-72.4.707

Soria, M. A., \& Bueno, D. J. (2016). Culture based methods to detect Salmonella from different poultry products. In E. Perkins (Ed.), Food microbiology: Fundamentals, challenges and health implications (pp. 57-86). New York, NY: Nova Science Publishers.

Soria, M. C., Soria, M. A., Bueno, D. J., \& Colazo, J. L. (2011). A comparative study of culture methods and polymerase chain reaction assay for Salmonella detection in poultry feed. Poultry Science, 90, 2606-2618. https://doi.org/10.3382/ps.2011-01548

Temelli, S., Eyigor, A., \& Carli, K. T. (2010). Salmonella serogroup detection in poultry meat samples by examining multiple colonies from selective plates of two standard culture methods. Foodborne Pathogens and Disease, 10, 1229-1234. https://doi.org/10.1089/fpd.2010.0570

Thung, T. Y., Mahyudin, N. A., Basri, D. F., Wan Radzi Mohamed, C. W. J., Nakaguchi, Y., Nishibuchi, M., \& Radu, S. (2016). Prevalence and antibiotic resistance of Salmonella enteritidis and Salmonella Typhimurium in raw chicken meat at retail markets in Malaysia. Poultry Science, 95, 1888-1893. https://doi.org/10.3382/ps/pew144

United States Department of Agriculture. (2017). National poultry improvement plan program standards. Washington, DC: United States Department of Agriculture.

Van der Zee, H. (2003). Media for isolation of Salmonella. In J. E. L. Corry, G. D. W. Curtis \& R. M. Baird (Eds.), Handbook of culture media for food microbiology (pp. 195-208). Amsterdam: Elsevier Science B.V. https:// doi.org/10.1016/S0079-6352(03)80016-4

Velma, Y. L., Goo, G., Ching, Q. L., \& Gooch, J. M. (1973). Comparison of brilliant green agar and Hektoen enteric agar media in the isolation of salmonellae from food products. Applied Microbiology, 26, 288-292.

Waltman, W. D. (2000). Methods for the cultural isolation of Salmonella. In C. Wray \& A. Wray (Eds.), Salmonella in domestic animals (pp. 355-372). Wallingford, UK: CABI Publishing. https://doi. org/10.1079/9780851992617.0000

World Organization for Animal Health (OIE) (2008). OIE terrestrial manual. Paris, France: OIE.

Xavier, J., Pascal, D., Crespo, E., Schell, H. L., Trinidad, J. A., \& Bueno, D. J. (2011). Seroprevalence of Salmonella and Mycoplasma infection in backyard chickens in the state of Entre Ríos in Argentina. Poultry Science, 90, 746-751. https://doi.org/10.3382/ps.2010-01036

How to cite this article: Rodríguez FI, Pascal DC, Pulido D, Osinalde JM, Caffer MI, Bueno DJ. Prevalence, antimicrobial resistance profile and comparison of selective plating media for the isolation of Salmonella in backyard chickens from Entre Rios, Argentina. Zoonoses Public Health. 2017;00:1-7. https:// doi.org/10.1111/zph.12415 